\title{
Suggesting Critical-Thinking and Problem-Solving Method into Teaching English Reading to EFL Students in Indonesia
}

\section{Idris Sadri, Rahmah Fithriani, Saidurrahman, Maryati Salmiah, and Sholihatul Hamidah}

Universitas Islam Negeri Sumatera Utara (UIN SU), Medan, Indonesia

\section{Abstract}

This article outlines the suggestion of critical-thinking and problem-solving into method to teach English reading to Indonesian EFL students. Since both terms could be elusively conceived by broad members of English language teacher or instructor and also the increasing demand of advance English proficiency, it could be perceived that picking up critical-thinking and problem-solving into teaching English reading in the EFL classroom would benefit to both teachers and students' classroom achievement regarding to their distinguished purposes on the language ability. The study was

Corresponding Author:

Idris Sadri

sadriidris@gmail.com

Received: 1 July 2019

Accepted: 18 July 2019

Published: 31 July 2019

Publishing services provided by Knowledge E

(c) Idris Sadri et al. This article is distributed under the terms of the Creative Commons

Attribution License, which permits unrestricted use and redistribution provided that the original author and source are credited.

Selection and Peer-review unde the responsibility of the AICLL 2019 Conference Committee.

\section{G OPEN ACCESS} conducted through reviewing a number of literatures outlining the implementation of the method in teaching English reading in the EFL classrooms. Moreover, the study also investigated the strengths and the weaknesses of the implementation of the method looked up through the vary of variables and cases on its implementation. It could be expected that this article could propose an idea to teaching English more effectively, efficiently, and advancing teachers and students' level of English language competence

Keywords: Critical-thinking, problem-solving, EFL, Indonesia

\section{Introduction}

As a global language, English become the world's most widely spoken language used by people of different mother tongues and countries of origin in immediate interactions (Fithriani, 2018). Therefore, the demand for higher level of English language proficiency increases significantly in latest days, particularly in countries where English serves as neither a first nor a national language. Its status as an international language plays enormously important in every aspect (Crystal, 2012). For that reason, the number of students who learn English as a second or foreign learners steadily rises to multiple to welcome global pace of life. This phenomenon can also be observed in Indonesia, where English is offered as the only foreign language mandatorily taught from secondary up to university level in Indonesia (Fithriani, 2017). However, the language competence 
does not come hand in hand with the enormous number of its learners. Test on English language proficiency is yet to challenge most of English learners ever since, either in the workplace or for study in overseas (Dörnyei, 1990). English learners found that English language proficiency test is unlikely to be passed over which require them to try more than one opportunity (Dörnyei, 1990).

One among skills tested in any English language proficiency test is reading comprehension skill. The test on reading comprehension skill designed to ensure test takers' ability on key issues or information extraction from the given sample of text (Richard \& Schmidt, 2013). The test takers would be presented to variety of questions forms such as yes or no statements and some sorts of multiple choices questions (Fulcher, 2014; Richard \& Schmidt, 2013). Overall, the test takers may be asked to read the given sample text and answer the questions from the reading text afterward (Fulcher, 2014). The length and the complexity of the language used in the given sample text would be increased to judge the level of proficiency (Richard \& Schmidt, 2013; Heinkel, 2011).

To its significance, in terms of teaching and learning language, reading comprehension skill deserves assiduous attention. In that context, reading is regarded as the most prominent considerations (Iqbal, Noor, Muhabat, \& Kazemian, 2001). It could be shown that within the last decade the significance of reading comprehension skill in the context of foreign language acquisition has explicitly burgeoned (Karbalaei, 2010). It also receives a consideration as a main element in academic context for students who learn English as a foreign language. It allows learners to obtain new information decoded through the given sample of reading text which could promote comprehension, interpretation, synthesizing, or understanding between lines assisting them in acquiring English as a foreign language (Klinger, Vaughn, \& Boardman, 2015).

Therefore, reading comprehension skill possesses its nature which is highly individual that is, no exact same way of approach utilized by two readers in processing the written text despite it has general factors that would give impact to (Rumelhart, 2017; McNamara, 2012). There could various works conducted to develop understanding of the implicating factors such as preference in the application of reading strategy and background knowledge relating to the written text. (Grabe \& Stoller, 2013).

To engage in the improvement of reading comprehension skill in the mean of students who learn English as a foreign language, teacher could apply critical-thinking and problem-solving as methods in teaching English to EFL students. Over decades, there would be a number of studies have been done to analyze the relationship between these two unities. As Limbach and Waugh (2010) and Zabit (2010) addressed the 
utilization critical thinking among other set of related concepts such as inferencemaking, prior knowledge, and metacognitive skills to explain and conceptualize reading comprehension through theoretical model provided by trends and theories which were promoted by some modern cognitivists.

In terms of problem-solving as another method to improve reading comprehension skill, the two things work hand in hand. Problem-solving as a method in teaching reading could be believed helping students to develop their ability in reading (Li, 2010). It could allow student to advance their English competence through reading (Limbach \& Waugh, 2010; Zabit, 2010; Li, 2010).

While some studies denote that it could be a hard challenge to teacher to develop classroom activity regarding to the application of these methods, it could be expected that the approach through these methods would give positive impact to the development of EFL students' skill in reading (Whimbey, Lochhead, \& Narode, 2013; McNamara, 2012; Kamali \& Fahim 2011). This article will discuss the suggestion of critical thinking and problem solving as method to improve EFL students' skill in reading comprehension.

\section{Literature Review}

Fahim and Barjasteh (2011) implied some critical pedagogical suggestions which are in line with what some scholars had added beforehand, such as Waters (2006) who believed that the application of activities which weight on critical thinking and problem solving as method to teach English reading in classroom context could improve the thinking levels of the learners and develop the language learners to decode the main point of the text as well despite they have different level of language proficiency. Critical thinking and problem-solving method are believed to help language learners to keep up and develop more understanding toward the information on the text. Therefore, it would allow the EFL learners to develop practicing the learning application in more integrative manner (Fahim \& Barjasteh, 2011; Waters, 2006).

Furthermore, Dianti (2015) outlined a number of key points on the application of critical thinking and its correlation to critical reading. The study points out that there is significant and positive impact of the application critical thinking to students' level of language proficiency in reading skill in terms of extending use of vocabulary, main topic and cause-effect identification, outlining details, figuring out the stance and the purposes of the writer, and inferring skills.

To add up what Dianti (2015) studied on the implication of the application of critical thinking toward improvement in reading skill, Apen (2016) summed up the use of 
problem solving method in teaching grammar, which could be positively integrated to teaching reading as knowledge on grammar is essential to develop skill of language learner in reading. The research shows that the challenge in the application of problemsolving method contributed to the improvement of language mastery. Moreover, it suggested that problem-solving technique promotes autonomy in learning.

\section{Research Method}

The study was conducted through reviewing a number of literatures outlining the implementation of the method in teaching English reading in the EFL classrooms. This method was utilized to review comprehensively about the subject matter and pose out a great deal of different perspectives on how critical thinking and problem-solving could overcome reading problem regarding to teaching and learning English (Gove, Vacca, Vacca, Burkey, Lenhart, and McKeon, 2011).

Furthermore, the essential points of this study are to provide new strategies to improve skill in reading and suggest those strategies to real context of English teaching and learning classroom. Thus, it may allow teachers and students to get better idea to perceive English reading in more significant and developed manner (Ness, 2016).

Moreover, the study also investigated the strengths and the weaknesses of the implementation of the method looked up through the vary of variables and cases on its implementation. It could be expected that this article could propose an idea to teaching English more effectively, efficiently, and advancing teachers and students' level of English language competence.

\section{Discussion}

\subsection{Definition of reading and its approach models}

In many studies, reading could be acknowledged as a process which has interactive nature connecting between reader and the reading text permitting fluency (in reading) (McPeck, 2016; Fahim, Barjasteh, \& Vaseghi, 2012; McNamara, 2012; Kamali \& Fahim 2011). Throughout this process, it enables interaction and connection between the reader to the reading text to elicit knowledge and meaning, putting together the role of linguistics or systemic knowledge and schematic knowledge as well in an occasion during reading (McPeck, 2016; Fahim, Barjasteh, \& Vaseghi, 2012). 
It is believed as a complex activity as Ahmadi, Ismail, and Abdullah (2013) contented that many studies have put forward to seek an attempt to describe and discover the fluency in the process of reading through the process of analysis a set of skills. There are a number of important skills and knowledge areas a reader should possess to lead him into fluence as many researchers took into account. Among them are; ability to recognize automatically, knowledge in vocabulary and grammatical structure, knowledge in determining structure of formal discourse, knowledge of background text, strategy in synthesizing and evaluating, and finally the metacognitive knowledge and monitoring (McNamara, 2012; Rosenshine, 2017).

Furthermore, experts announced three major approaches frequently involved in reading dealing with information and knowledge processing; they are bottom up processing which could begin from identification words from the structure of their letter, and then followed by sentences from the structure of their words (Grabe \& Stroller, 2013). Another model Grabe and Stroller (2013) introduced is top-down approach which furtherly extends from just meaning extraction from the text to the process of synthesizing information and connecting them in the text with knowledge which the reader carries forward to the reading activity. Meaning that, the readers who are involved in reading activities should possess the background knowledge or information and competence in language as well which allow them to understand cues in the text and leading to the activation of schemata (Cahyono \& Mukminatien, 2011). This model of approach seeks more attention to comprehension with a few on phonology, syntax, and semantics in the system of the language (2011). Therefore, in this model of approach, students would be encouraged to try to guess the meaning of the words, assuming what the writer might say, reading for main ideas, and recalling background experience or information (2011). In compare to the previous one, this model of approach could be inapplicable to some beginner EFL students who are still struggling to put together correspondence of sound and symbols of English (2011). The last model of approach is interactive (Gova, Vacca, Vacca, Burkey, lenhart, \& McKeon, 2011). This model of approach promotes the combination of the two previously mentioned models; the bottom-up and the top-down which could incorporate processing information parallelly from the exact printings and information which are reflected in the background knowledge (Gova, Vacca, Vacca, Burkey, lenhart, \& McKeon, 2011; Dechant, 2013; Lesgold \& Perfetti, 2017). All of those mentioned models aim to promote recognition which allow the reading to constructing the meaning of text through decoding letters as the smallest unit in the reading text, words, sentences, and paragraphs and comprehension of reading text and ideas or 
information as the final result (Oakhill, Cain, \& Elbro, 2014; Gova, Vacca, Vacca, Burkey, Lenhart, \& McKeon, 2011; Dechant, 2013; Lesgold \& Perfetti, 2017).

\subsection{Critical-thinking and problem-solving method}

In context of education, critical thinking has been widely regarded to education. It could be showed that in the $8^{\text {th }}$ Annual International Conference on Critical Thinking and Education reform maintained a description of critical thinking as an active process that could require an intellectual discipline that encourages to quest after thought on many objectives such as new idea exploration, decoding truth among situation, approaching issues and problems, revealing assumptions, analyzing concept, setting up line to separate what we know and what we about to know, and explaining logical setting of implication of thought (Halpern, 2014). Therefore, critical thinking should cover major activities that always possibly hand in hand with such analyzing, conceptualizing, synthesizing, evaluation of information, applying, generating an observation and experience, and so forth. Another definition proposed by Halpern (2014) stated that critical thinking is a purposeful, objective, and reasonable activity which utilization of cognitive skills works to increase the level of probability of the desirable result. Paul and Scriven as mentioned by Condon and Kelly-Riley (2004) entailed critical thinking as the examination of thought elements in any regard of reasoning implicitly either on problem, purpose, assumption, prediction, inquiries, concepts, or ground of empirical background to frame the thought alternatives or different viewpoint about something. Extensively, Wilson (2016) defined a critical thinker as a purposeful, reasonable, and goal directed thinker in compare to non-critical thinker which requires early nurturing and thought.

Critical thinking covers some elemental aspects such as judgement, interpretative reasoning analysis, comprehension, application and evaluation (McPeck, 2016). Critical thinkers may see language activities such as reading, listening, writing, and reading as modes of skilled thinking (Fahim, 2016; Fahim \& Kamali, 2011). They do reading as a process to view the reading text as a verbal representation of the author. They put forward attempt to analyze the writer's point of view. Furthermore, they even try to reconstruct and rephrase the author's purpose by their own language (Fahim \& Kamali, 2011).

In terms of foreign language learning, it could be no doubt that thought, and language are interrelated. Language could represent thought of individual's mind. This could be investigated in skill which require comprehension such as reading. As Nunan (1999) 
believed that reading is unlike speaking which every individual learns to do. Moreover, it could be said that well learning is supported by well reading as pointed out by Elder and Paul (2006).

Dealing with problem solving as another model of approach which allows to comprehension in reading, it might require a great deal of skill that incorporate together regarding to its complexity within its process (Nunan, 1999). Other than that, problem solving as method to enhance skill in reading and to promote comprehension supposed to be along with critical thinking to some extent.

Problem solving method allows the students to elaborate their language abilities and prior knowledge to decode and gain new information or knowledge from the reading text (Pressley \& Afflerbach, 2012). It is often that the students may struggle with the reading text to bring about the task given by the teacher. Some of them might believe that they could not highly compromise to words or sentences that may look unfamiliar to them (Karbalaei, 2010).

Problem solving method could help students to activate their awareness to highly unfamiliar reading text through activating the schemata and/or background information and let them observe and finish by utilizing mindful word-to-word or sentence-tosentence interconnection purposefully they have learned since very early engagement to the reading text (Whibey, Lochhead, \& Narode, 2013).

\subsection{Implication of the methods of teaching reading in EFL class- room}

In EFL classroom context, it could be common mystification about the most proper strategy to teach reading comprehension to the students. It may be adequately tricky and seriously challenging to discover the applicable formula to make teaching and learning activity become more engaging and productive (Hamra \& Syatriana, 2015).

One suggestion to search the effective approach in teaching reading in EFL classroom is to examine the reading process models. Some experts suggest the three different model that could involve the reading process of students in EFL classroom context. Birch (2014) and Lambe (2018) proposed bottom-up model that suggests the reading activity could be performed when the students have learnt letters of alphabet and being aware of the structure of words and phrases inseparably. The proponents of the previouslymentioned statement regarded reading as a linear process by which enable students to extract a reading text from one word to another word and putting the words into sentence or phrase (Iwai, 2011). 
Moreover, it could be said that reading supposed to be constant and repeated process to search, predict, crosscheck, and correct belief and assumption picked up from the reading text. the students may have been coming from different abilities regarding to how much prior knowledge they may have gained before they submit themselves into the reading text (McNamara, 2012). The teacher could help them to activate those prior knowledges and attempt to connect such prior knowledges to the background of information on the reading text.

Difference in prior experience and knowledge of the students could be a bridge to allow recognition, automaticity, and comprehension through some purposeful pre and post reading activity (McNamara, 2012; Nash-Ditzel, 2010). It may cover searching for particular information, recognized words, known features of the text, formulation of syntax; construct a prediction through managing expectation and anticipation on what will come after connecting prior knowledge and experience to fact or information interpreted from the reading text; cross-checking and confirmation to indicate that the reading activity makes sense and contributes to the entire information that has been already processed; and finally self-correction to identify errors that have been made and seek for more information to gain the correct meaning or interpretation (Nash-Ditzel, 2010).

The combination of critical thinking and problem solving as a method in teaching reading comprehension could help the students to get higher score in reading significantly. Those strategies could promote students-based learning environment where the teacher could enhance the different ability of students as bridge to understanding, decoding, and putting forward the fact and information within the reading text effectively and purposefully (Li \& Wang, 2010; Nash-Ditzel, 2010).

Therefore, the learning process would not be centered on teacher only which has been done during few past times. The teacher should creatively create a new classroom environment which emphasizes empowerment to students' ability and knowledge.

\section{Conclusion}

Seeking for the highly impacted strategy to develop classroom learning environment could challenge and be tricky to some extent. The preferred strategy could not also help teachers to engage within the classroom. Teacher seems to apply different strategy to different classroom environment purposefully to let them know which strategy that could be applied effectively. 
Problem solving and critical thinking could provide more advance insight to teacher to engage with the classroom environment on teaching reading comprehension to EFL students. it may help teacher to activate and consolidate prior knowledge and different ability of students to decode, understanding, and solve the task within the reading text.

Therefore, it would be best to suggest those two strategies to develop comprehension of students in reading by the benefits and procedures that have been outlined before this part. However, despite the strategies would be the same in nature and definition, the practical application would be dependable regarding to which kind of classroom environment the learning works on.

\section{References}

[1] Ahmadi, M. R., Ismail, H. N., \& Abdullah, M. K. K. (2013). The Importance of Metacognitive Reading Strategy Awareness in Reading Comprehension. English Language Teaching, 6(10), pp. 235-244.

[2] Apen, R. (2016). The Applicative Use of Problem Solving Technique in Teaching Grammar. Proceedings of ISELT FBS Universitas Negeri Padang, 4(2), 180-187.

[3] Birch, B. M. (2014). English L2 reading: Getting to the bottom. London: Routledge.

[4] Cahyono, B. Y., \& Mukminatien, N. (2011). Techniques and Strategies to Enhance English Language Learning.

[5] Crystal, D. (2012). English as a global language. The UK: Cambridge University Press.

[6] Dechant, E. (2013). Understanding and teaching reading: An interactive model. London: Routledge.

[7] Dianti, R. (2015). The correlation between critical thinking skills and critical reading skills of the English education study program students of Sriwijaya University. Edukasi: Jurnal Pendidikan dan Pengajaran, 2(1), 43-54.

[8] Dörnyei, Z. (1990). Conceptualizing motivation in foreign-language learning. Language learning, 40(1), pp. 45-78.

[9] Elder, L., \& Paul, R. (2006). The Thinker's Guide to Analytic Thinking: How to Take Thinking Apart and what to Look for when You Do: The Elements of Thinking and the Standards They Must Meet. The US: Foundation for Critical Thinking.

[10] Fahim, M., Barjesteh, H., \& Vaseghi, R. (2012). Effects of Critical Thinking Strategy Training on Male/Female EFL Learners' Reading Comprehension. English Language Teaching, 5(1), 140-145. 
[11] Fithriani, R. (2017). Indonesian students' perceptions of written feedback in second language writing (Doctoral Dissertation). Retrieved from https://digitalrepository. unm.edu/educ_llss_etds/87/

[12] Fithriani, R. (2018). Discrimination behind NEST and NNEST Dichotomy in ELT Professionalism. in The 1st Annual International Conference on Language and Literature, KnE Social Sciences, (pp. 741-755). DOI 10.18502/kss.v3i4.1982

[13] Fulcher, G. (2014). Testing second language speaking. London: Routledge.

[14] Gove, M., Vacca, J. A. L., Vacca, R. T., Burkey, L. C., Lenhart, L. A., \& McKeon, C. A. (2011). Reading and learning to read. London: Pearson.

[15] Grabe, W. P., \& Stoller, F. L. (2013). Teaching and researching: Reading. London: Routledge.

[16] Halpern, D. F. (2014). Critical thinking across the curriculum: A brief edition of thought \& knowledge. London: Routledge.

[17] Hamra, A., \& Syatriana, E. (2015). Developing a model of teaching reading comprehension for EFL students. TEFLIN journal, 21(1), 27-40.

[18] Hinkel, E. (Ed.). (2011). Handbook of research in second language teaching and learning (Vol. 2). London: Routledge.

[19] Iqbal, M., Noor, M., Muhabat, F., \& Kazemian, B. (2015). Factors responsible for poor English reading comprehension at secondary level. Communication and Linguistics Studies, 1(1), 1-6.

[20] Iwai, Y. (2011). The effects of metacognitive reading strategies: Pedagogical implications for EFL/ESL teachers. The Reading Matrix 11 (2), 150, 159.

[21] Kamali, Z., \& Fahim, M. (2011). The relationship between critical thinking ability of Iranian EFL learners and their resilience level facing unfamiliar vocabulary items in reading. Journal of Language Teaching \& Research, 2(1).

[22] Karbalaei, A. (2010). A comparison of the metacognitive reading strategies used by EFL and ESL readers. The Reading Matrix, 10(2).

[23] Klingner, J. K., Vaughn, S., \& Boardman, A. (2015). Teaching reading comprehension to students with learning difficulties, 2/E. NY: Guilford Publications.

[24] Lambe, L. (2018). Teaching reading comprehension in EFL classroom: A glance at some approaches and activities. Journal of English Language and Literature Teaching, 2(02).

[25] Lesgold, A. M., \& Perfetti, C. A. (2017). Interactive processes in reading. London: Routledge. 
[26] Li, F. (2010). A study of English reading strategies used by senior middle school students. Asian Social Science, 6(10), 184.

[27] Whimbey, A., Lochhead, J., \& Narode, R. (2013). Problem solving \& comprehension: A short course in analytical reasoning. London: Routledge.

[28] Li, Y., \& Wang, C. (2010). An empirical study of reading self-efficacy and the use of reading strategies in the Chinese EFL context. Asian EFL Journal, 12(2), 144-162.

[29] Limbach, B., \& Waugh, W. (2010). Developing Higher Level Thinking. Journal of Instructional Pedagogies, 3.

[30] McNamara, D. S. (Ed.). (2012). Reading comprehension strategies: Theories, interventions, and technologies. The UK: Psychology Press.

[31] McPeck, J. E. (2016). Teaching critical thinking: Dialogue and dialectic. Routledge.

[32] Nash-Ditzel, S. (2010). Metacognitive reading strategies can improve selfregulation. Journal of College Reading and Learning, 40(2), 45-63.

[33] Ness, M. K. (2016). Reading comprehension strategies in secondary content area classrooms: Teacher use of and attitudes towards reading comprehension instruction. Reading Horizons, 49(2), 5.

[34] Nunan, D. (1999). Second Language Teaching \& Learning. Heinle \& Heinle Publishers, 7625 Empire Dr., Florence, KY 41042-2978.

[35] Oakhill, J., Cain, K., \& Elbro, C. (2014). Understanding and teaching reading comprehension: A handbook. London: Routledge.

[36] Pressley, M., \& Afflerbach, P. (2012). Verbal protocols of reading: The nature of constructively responsive reading. London: Routledge.

[37] Richards, J. C., \& Schmidt, R. W. (2013). Longman dictionary of language teaching and applied linguistics. London: Routledge.

[38] Rosenshine, B. V. (2017). Skill hierarchies in reading comprehension. In Theoretical issues in reading comprehension (pp. 535-554). London: Routledge.

[39] Rumelhart, D. E. (2017). Schemata: The building blocks of cognition. In Theoretical issues in reading comprehension (pp. 33-58). London: Routledge.

[40] Whimbey, A., Lochhead, J., \& Narode, R. (2013). Problem solving \& comprehension: A short course in analytical reasoning. London: Routledge.

[41] Wilson, K. (2016). Critical reading, critical thinking: Delicate scaffolding in English for academic purposes (EAP). Thinking Skills and Creativity, 22, 256-265.

[42] Zabit, M. N. M. (2010). Problem-based learning on students' critical thinking skills in teaching business education in Malaysia: A literature review. American Journal of Business Education, 3(6), 19-32. 